\title{
Priapism in Homozygous Sickle Cell Patients: Important Clinical and Laboratory Associations
}

\author{
Anazoeze Jude Madu ${ }^{a}$ Agozie Ubesie $^{b}$ Sunday Ocheni ${ }^{a} \quad$ Josephat Chinawa ${ }^{b}$ \\ Kenechi Anthony Madu ${ }^{c}$ Obike Goodswill Ibegbulam ${ }^{a} \quad$ Charles Nonyelu $^{a}$ \\ Alozie Eze ${ }^{a}$
}

Departments of a Haematology and Immunology and ${ }^{b}$ Pediatrics, College of Medicine, University of Nigeria Enugu Campus, and ${ }^{\mathrm{C}}$ National Orthopaedic Hospital, Enugu, Nigeria

\section{Key Words}

Priapism · Sickle cell · Erectile dysfunction · Severe disease

\begin{abstract}
Objective: To evaluate the relationship between the occurrence of priapism and important steady-state clinical and laboratory parameters in homozygous sickle cell disease (SCD). Subjects and Methods: Steady-state clinical and laboratory data were obtained from the medical records of 126 male patients seen in the clinic over a 7-year period. Estimated prevalence rates, correlation coefficients and independent $t$ tests were calculated to assess the relationship between priapism and several important clinical and laboratory indices. Patient data on age, haemoglobin concentrations, the frequency of crises per annum, leucocyte counts, platelet counts, serum bilirubin and aspartate transaminase were evaluated. Results: The prevalence of priapism was determined to be $21.4 \%$, and $22.2 \%$ of those affected had erectile dysfunction. There was a significant positive correlation between priapism and older age $(p=0.049)$ and lower leucocyte counts $(p=0.008)$. There was no significant relationship with other clinical or laboratory indices. Conclusion: About 1 in 4 of all homozygous older SCD patients had pria-
\end{abstract}

\begin{tabular}{ll}
\hline KARGER & $\begin{array}{l}\text { ( } 2014 \text { S. Karger AG, Basel } \\
1011-7571 / 14 / 0233-0259 \$ 39.50 / 0\end{array}$ \\
E-Mail karger@karger.com & $\begin{array}{l}\text { This is an Open Access article licensed under the terms of the } \\
\text { www.karger.com/mpp }\end{array}$ \\
$\begin{array}{l}\text { Creative Commons Attribution-NonCommercial 3.0 Un- } \\
\text { ported license (CC BY-NC) (www.karger.com/OA-license), } \\
\text { applicable to the online version of the article only. Distribu- } \\
\text { tion permitted for non-commercial purposes only. }\end{array}$
\end{tabular}

pism, and an approximately similar ratio developed erectile dysfunction; they also had lower steady-state leucocyte counts. Other clinical and laboratory indicators of disease severity in SCD did not positively correlate with the occurrence of priapism, and this may imply an alternative pathogenetic mechanism.

(c) 2014 S. Karger AG, Basel

\section{Introduction}

Sickle cell anaemia (SCA) is a haemoglobinopathy with associated chronic haemolysis; more than 300,000 children are born annually with this condition [1]. Episodic vaso-occlusion at the post-capillary venules by sickled red cells is the hallmark of the pathophysiology of this condition. Recent findings have indicated a positive association of these events with leucocyte counts and platelet values as well as haemolysis-associated depletion of vascular nitric oxide [2].

Priapism is a persistent (lasting more than $4 \mathrm{~h}$ ) painful erection of the penis occurring with or without sexual stimulation. The condition was first defined by Tripe in 1845 and is named after Priapus - the Greek god of fertil-
Dr. Anazoeze J. Madu

Department of Haematology and Immunology

University of Nigeria Enugu Campus (UNEC), PMB 01129

Enugu 400001 (Nigeria)

E-Mail Anazoeze@gmail.com 
ity [3]. The majority of cases occur in sickle cell disease (SCD); however, other disease conditions with hyperviscosity may also cause priapism [4]. Two types of priapism are clinically relevant, i.e. the ischaemic, veno-occlusive (low-flow) type and the non-ischaemic, arterial (highflow) type. The high-flow (non-ischaemic) type is due to the formation of artero-sinusoidal shunts, which feed the cavernosa and circumvent the restrictive arteriolar vasoconstriction [5], while the low-flow (ischaemic) type is due to sinusoidal thrombosis with veno-occlusion not involving the cavernosal blood flow [3]. Apart from a few clinical clues - absence of pain and rigidity - in most cases of non-ischaemic priapism the difference is usually discerned with certainty using ultrasonography.

Several genetic markers have been implicated in the pathophysiology of priapism in SCA. Klotho, a membrane protein that regulates nitric oxide synthase, has been associated with priapism in SCD [6]. Another marker singled out as the most potent trigger of priapism is integrin, a subunit of the $\alpha_{\mathrm{V}}-\beta_{3}$ endothelial adhesion molecule that is believed to bind sickle erythrocytes to the endothelium via intermediary proteins thrombospondin, von Willebrand factor and ICAM-4 [7].

Other possible pathways in the pathogenesis of priapism were proposed by Okpala [8] in 2006. He observed that leucocyte adhesion, recurrent inflammation, vasculopathy, depletion of omega-3 fatty acids and an increase in the concentration of microparticles and cell-free haemoglobin $(\mathrm{Hb})$ as well as red blood cell arginase and eventual depletion of nitric oxide availability are all indirectly involved in the pathogenesis of priapism. In addition, Kuypers et al. [9] noted that loss of normal membrane phospholipid asymmetry is present in a subpopulation of red blood cells in SCA. This loss of asymmetry may lead to repeated cycles of sickling and unsickling, resulting in polymerization and depolymerization with the production of microparticles. The abnormal phospholipid asymmetry and microparticles contain phosphatidylserine, which indeed alters the adhesive properties of sickle red blood cells. This also depletes nitric acid and alters the endothelial membranes, especially ICAM and VCAM. This membranopathy as a mechanism of priapism in SCA has also been corroborated by Nolan et al. [2].

The degree of haemolysis has been found to be related to the occurrence of priapism, mostly likely via the consumption of nitric oxide (endothelium-derived relaxation factor) [2]. Other clinical and laboratory indicators of disease severity in SCA, such as the presence of other chronic complications, the frequency of crises, $\mathrm{Hb}$ con- centrations and leucocyte and platelet counts, have also been determined to correlate with the degree of haemolysis. However, clinical observation indicates that priapism may not be associated with severe SCD. Previous studies have also suggested some relationship between the occurrence of priapism and serum bilirubin, lactate dehydrogenase and aspartate enzyme in SCD, although studies of this type on homozygous $S$ patients are sparse. However, the occurrence and effect of other abnormal Hbs beyond $\mathrm{HbS}$ may obviate some of these complications.

Previous studies have provided insight into the relationship between the indicators of disease severity in SCA and various complications of the disease [10]. This study aimed to examine the occurrence of and relationship between priapism and important steady-state clinical and laboratory parameters in homozygous $S$ patients.

\section{Subjects and Methods}

This is a retrospective study of all male patients who were diagnosed with SCA and were seen at the adult sickle cell clinic of the University of Nigeria Teaching Hospital (UNTH), Enugu, Nigeria, between August 2006 and July 2013. Approval was obtained from the UNTH Health Research and Ethics Committee. Demographic as well as steady-state clinical data were extracted from the patients' medical records. Patients who were not HbSS on $\mathrm{Hb}$ electrophoresis were excluded from this study. Data analysed included age, sex, the frequency of bone pain crises per annum, steady-state serum direct bilirubin, aspartate transaminase (AST), Hb concentration and leucocyte and platelet counts. For the purposes of this study, steady-state values were recorded as values obtained during the absence of a crisis or clinically obvious infection in the patient. The correlations between the frequency of bone pain crises, serum alanine transaminase, $\mathrm{PCV}, \mathrm{Hb}$ concentration, platelet and leucocyte counts and the occurrence of priapism were then computed.

\section{Statistics}

Using GraphPad StatMate 2.0 software (GraphPad Software, San Diego, Calif., USA), the power of this study varied from 75 to 95\% for the various variables mentioned above in patients with priapism. Parametric (Spearman's rho) correlation coefficients (2-tailed) as well non-parametric (independent $t$ test) ones were then obtained for each variable and presented in tabular form. $\mathrm{p}<$ 0.05 was considered statistically significant. Analyses were performed using Statistical Package for Social Sciences (SPSS) version 17.0 (Chicago, Ill., USA) for Windows.

\section{Results}

We retrieved the medical records of 126 male patients between 13 and 55 years of age. The median age was 24 years. The prevalence of priapism in this group was $21.4 \%$; 
Table 1. Clinical and steady-state laboratory parameters amongst adult males with homozygous SCD

\begin{tabular}{|c|c|c|c|c|c|}
\hline & $\mathrm{n}$ & Mean (SD) & Median & $\begin{array}{l}\text { Independent } \\
t \text { test } p \text { value }\end{array}$ & $\begin{array}{l}\text { Correlation } \\
\text { coefficient } \\
\text { (significance) }\end{array}$ \\
\hline \multicolumn{6}{|l|}{ Age (years) } \\
\hline All patients & 123 & $24.9(7.0)$ & 24 & \multirow{3}{*}{$0.049^{*}$} & \multirow{3}{*}{$-0.232(0.010)^{*}$} \\
\hline Priapism & 28 & $26.8(5.4)$ & 26 & & \\
\hline No priapism & 95 & $24.3(7.3)$ & 23 & & \\
\hline \multicolumn{6}{|c|}{ Frequency of crises per annum } \\
\hline All patients & 72 & $3(4.8)$ & 2 & \multirow{3}{*}{0.271} & \multirow{3}{*}{$0.116(0.165)$} \\
\hline Priapism & 24 & $3(3.2)$ & 3 & & \\
\hline No priapism & 48 & $4(5.4)$ & 3 & & \\
\hline \multicolumn{6}{|c|}{ Leucocyte count $\left(\times 10^{9} / l\right)$} \\
\hline All patients & 115 & $13.1(7.5)$ & 11.2 & \multirow{3}{*}{$0.008^{*}$} & \multirow{3}{*}{$0.234(0.012)^{*}$} \\
\hline Priapism & 27 & $10.5(4.5)$ & 8.9 & & \\
\hline No priapism & 88 & $13.9(8.0)$ & 11.7 & & \\
\hline \multicolumn{6}{|c|}{ Platelet count $\left(\times 10^{9} / \mathrm{l}\right)$} \\
\hline All patients & 104 & $346(150)$ & 323 & \multirow{3}{*}{0.359} & \multirow{3}{*}{$0.112(0.257)$} \\
\hline Priapism & 25 & $323(141)$ & 302 & & \\
\hline No priapism & 79 & $354(152)$ & 347 & & \\
\hline \multicolumn{6}{|c|}{ Hb concentration $(g / d l)$} \\
\hline All patients & $99^{\circ}$ & $7.8(1.7)$ & 7.8 & \multirow{3}{*}{0.683} & \multirow{3}{*}{$-0.006(0.951)$} \\
\hline Priapism & 23 & $7.9(1.6)$ & 7.7 & & \\
\hline No priapism & 76 & $7.8(1.7)$ & 7.8 & & \\
\hline \multicolumn{6}{|c|}{ Indirect bilirubin } \\
\hline All patients & 67 & $15.2(24.9)$ & 8.6 & \multirow{3}{*}{0.239} & \multirow{3}{*}{$-0.002(0.981)$} \\
\hline Priapism & 17 & $11.3(7.8)$ & 8.6 & & \\
\hline No priapism & 50 & $28.3(28.2)$ & 8.6 & & \\
\hline \multicolumn{6}{|c|}{ Direct bilirubin } \\
\hline All patients & 68 & $26.7(33.5)$ & 17.3 & \multirow{3}{*}{0.404} & \multirow{3}{*}{$0.005(0.966)$} \\
\hline Priapism & 17 & $22.2(20.5)$ & 12.8 & & \\
\hline No priapism & 51 & $28.2(36.9)$ & 17.5 & & \\
\hline \multicolumn{6}{|l|}{ Serum AST } \\
\hline All patients & 66 & $21.9(19.2)$ & 17.0 & \multirow{3}{*}{0.877} & \multirow{3}{*}{$0.28(0.822)$} \\
\hline Priapism & 17 & $21.4(17.3)$ & 15.0 & & \\
\hline No priapism & 49 & $22.1(19.9)$ & 17.0 & & \\
\hline
\end{tabular}

* Significant at $\mathrm{p}<0.05$.

$22.2 \%$ of those patients had erectile dysfunction and 92.3\% had a history of repeated episodes (more than one incidence) of priapism.

The observed median steady-state values were: leucocyte count, $11.4 \times 10^{9} / \mathrm{l}$; platelet count, $323 \times 10^{9} / \mathrm{l}$; $\mathrm{Hb}$ concentration, $7.8 \mathrm{~g} / \mathrm{dl}$; PCV, $0.24 \mathrm{l} / \mathrm{l}$; total bilirubin, 25.9 $\mu \mathrm{mol} / \mathrm{l}$; direct bilirubin, $17.3 \mu \mathrm{mol} /$; serum AST, $17 \mathrm{IU} / \mathrm{l}$; alanine transaminase, $11 \mathrm{IU} / \mathrm{l}$, and alkaline phosphatase, $58.5 \mathrm{IU} / \mathrm{l}$. The average number of crises per annum for the group was 3 episodes per year. The mean and median values for patients with and without a history of priapism, as well as their correlation coefficients and independent $t$

Priapism in Homozygous Sickle Cell Patients test values, are listed in table 1 . The results of an independent samples $t$ test for the equality of means (assuming unequal variance) and their $\mathrm{p}$ values are also given in table 1 . Amongst the clinical and steady-state laboratory values, there was a significant positive relationship between the occurrence of priapism and increasing age as well as a low leucocyte count ( $\mathrm{p}=0.049$ and $\mathrm{p}=0.008$, respectively). Also noted was a positive correlation between priapism and increasing age $(\mathrm{p}=0.010)$.

Serum AST, the frequency of crises, the $\mathrm{Hb}$ concentration and bilirubin (direct and indirect) were all found to have a poor relationship with the occurrence of priapism.

Echocardiography for screening of pulmonary hypertension in SCD is not routinely done for all patients attending the clinic. However, of the patients included in this study, 2 had been diagnosed with pulmonary hypertension and none of them had a history of priapism as at the time of the study. The patients included in this study were still being seen as outpatients, and no active management of SCD was used as neither hydroxyurea nor stem cell transplant is offered routinely.

\section{Discussion}

The $21.4 \%$ prevalence rate of priapism obtained in this study is similar to the rate of $28 \%$ obtained by Mantadakis et al. [11] and lower than the 35\% found in Nigerians [12] and the 37\% in the UK group reported by Adeyoju et al. [13]. However, it must be noted that their study included other heterozygous forms of sickle cells besides HbSS. The variability in the prevalence of priapism reported by various studies could be due to other environmental factors as well as the presence of other abnormal $\mathrm{Hb}$ types that may have contributed to the variety of effects.

Previous studies have implicated several precipitating factors including fever, asplenia, sexual arousal and dehydration in the occurrence of priapism $[13,14]$. The study by Adeyoju et al. [13] of patients in different centres in the UK and Nigeria showed that $75 \%$ of the patients had experienced their first episode by their 20th birthday [13]. Approximately $19 \%$ of the patients in this study were below 20 years of age and there was no report of priapism amongst them. This may be partly due to the lack of disclosure and suboptimal communication between the physician and the patient, especially in issues related to sex.

Erectile dysfunction, as shown by this study, was a prominent complication of priapism, occurring in ap- 
proximately 1 of 5 patients. This complication is usually marked by depression and other attendant psychosocial problems, such as the patient finding it difficult to maintain meaningful relationships with persons of the opposite sex [15], thus jeopardizing his marital prospects. A great number $(92.3 \%)$ of those who had priapism had more than one episode and required hospital admission. This could explain the high incidence of erectile dysfunction, as late presentation to the clinic or accident and emergency were other observed key factors.

Because the median age of the patients studied was 24 years and because of the significant relationship between the occurrence of priapism and older age, it might not be surprising that sexual arousal/ intercourse has been noted in previous studies to be of aetiological importance [13, 16]. It is noteworthy that studies have shown that the incidence tends to plateau as patients approach 30 years of age and beyond [13].

The frequency of crises per annum, another indicator of illness severity in SCD, did not show a positive association with the occurrence of priapism. This can be deduced from what is known about the pathophysiologic mechanism of priapism, which varies to some extent from the mechanisms of other forms of crisis in SCD. A previous study by Yuan et al. [17] implicated the downregulation of penile phosphodiesterase type 5, which causes a reduction in cyclic guanidine monophosphate involved in nitric oxide-induced smooth muscle relaxation. This effect is to a large extent localised to the penis and is non-systemic and therefore could partly explain the lack of association with severe disease.

The positive correlation between a low leucocyte count and the occurrence of priapism is contrary to the observations of Nolan et al. [2] in an American cohort, and it may be an indicator of the difference in pathogenesis between priapism and the vaso-occlusion observed in SCD. The findings of this study also explain why hydroxycarbamide, which causes leucodepletion, has not been effective in the treatment or prophylaxis of priapism.

Nolan et al. [2] reported a positive relationship between priapism and a low $\mathrm{Hb}$ concentration as well as high platelet counts, serum AST and bilirubin, but this was not confirmed in our study. The study by Ahmed et al. [18] reported a higher $\mathrm{Hb}$ concentration in HbSS patients who had priapism compared to those who did not. There was no significant difference in the $\mathrm{Hb}$ concentration of the 2 groups in our study, and this may be partly explained by variations in environmental as well as dietary or other genetic factors which may play an important part in the occurrence of priapism found in SCD.
The observed lack of an association with platelet counts and $\mathrm{Hb}$ concentration may be partly explained by the fact that transfusion and drugs like hydroxycarbamide (aimed at increasing the $\mathrm{Hb}$ concentration and reducing the platelet count) have not been very effective in the treatment or prophylaxis of this condition $[13,19]$. This is evidenced both by clinical experience and by the report by Adeyoju et al. [13], which showed that analgesia, rehydration and possibly exchange blood transfusion were the preferred treatment modalities amongst physicians [13, 16, 20]. However, exchange blood transfusion, aimed at reducing the HbS percentage as well as improving haematocrit levels, does not usually yield satisfactory results [21]. This raises obvious doubts as to the similarity of pathogenetic processes between priapism and other forms of sickle cell crisis. The peculiarity of the environmental factors in the various geographical locations where patients reside, as well as the possibility of interplay with other genetic factors which may not be directly related to the $\mathrm{HbS}$ gene, could possibly play a role.

\section{Conclusion}

This study revealed that priapism occurred in $21.4 \%$ of homozygous sickle cell patients, $22.9 \%$ of whom developed erectile dysfunction. In this study group, older age and a low leucocyte count were observed to be associated with the occurrence of priapism, while other clinical and laboratory indicators of severe disease (frequency of crises, $\mathrm{Hb}$ concentration, platelet count, serum AST and bilirubin) did not show significant relationships. This indicates that an alternative aetiopathogenetic pathway rather than that seen in vaso-occlusion may be involved in priapism in SCD patients.

References

1 Anie KA, Egunjobi FE, Akinyanju OO: Psychosocial impact of sickle cell disorder: perspectives from a Nigerian setting. Global Health 2010;6:2.

2 Nolan VG, Wyszynski DF, Farrer LA, et al Hemolysis-associated priapism in sickle cell disease. Blood 2005;106:3264-3267.

3 Halls JE, Patel DV, Walkden M, et al: Priapism: pathophysiology and the role of the radiologist. Br J Radiol 2012;85:S79-S85.

4 Hamre MR, Harmon EP, Kirkpatrick DV, et al: Priapism as a complication of sickle cell disease. J Urol 1991;145:1-5.

5 Bastuba MD, Saenz de Tejada I, Dinlenc CZ, et al: Arterial priapism: diagnosis, treatment and long-term followup. J Urol 1994;151: 1231-1237. 
6 Halabi-Tawil M, Lionnet F, Girot R, et al: Sickle cell leg ulcers: a frequently disabling complication and a marker of severity. $\mathrm{Br} \mathrm{J}$ Dermatol 2008;158:339-344.

7 Nolan VG, Baldwin C, Ma Q, et al: Association of single nucleotide polymorphisms in klotho with priapism in sickle cell anaemia. $\mathrm{Br}$ J Haematol 2005;128:266-272.

-8 Okpala I: Leukocyte adhesion and the pathophysiology of sickle cell disease. Curr Opin Hematol 2006;13:40-44.

-9 Kuypers FA, Lewis RA, Hua M, et al: Detection of altered membrane phospholipid asymmetry in subpopulations of human red blood cells using fluorescently labeled annexin V. Blood 1996;87:1179-1187.

10 Okpala I: The intriguing contribution of white blood cells to sickle cell disease - a red cell disorder. Blood Rev 2004;18:65-73.
11 Mantadakis E, Cavender JD, Rogers ZR, et al: Prevalence of priapism in children and adolescents with sickle cell anemia. J Pediatr Hematol Oncol 1999;21:518-522.

12 Olujohungbe AB, Adeyoju A, Yardumian A, et al: A prospective diary study of stuttering priapism in adolescents and young men with sickle cell anemia: report of an international randomized control trial - the priapism in sickle cell study. J Androl 2011;32:375-382.

-13 Adeyoju AB, Olujohungbe AB, Morris J, et al: Priapism in sickle-cell disease: incidence, risk factors and complications - an international multicentre study. BJU Int 2002;90:898-902.

14 Kato GJ: Priapism in sickle-cell disease: a hematologist's perspective. J Sex Med 2012;9: 70-78.

15 Park K, Hwang EC, Kim SO: Prevalence and medical management of erectile dysfunction in Asia. Asian J Androl 2011;13:543-549.

16 Jesus LE, Dekermacher S: Priapism in children: review of pathophysiology and treatment. J Pediatr (Rio J) 2009;85:194-200.
7 Yuan J, Desouza R, Westney OL, et al: Insights of priapism mechanism and rationale treatment for recurrent priapism. Asian J Androl 2008;10:88-101.

18 Ahmed SG, Ibrahim UA, Hassan AW: Hematological parameters in sickle cell anemia patients with and without priapism. Ann Saudi Med 2006;26:439-443.

19 Montague DK, Jarow J, Broderick GA, et al: American Urological Association guideline on the management of priapism. J Urol 2003; 170:1318-1324.

20 Merritt AL, Haiman C, Henderson SO: Myth: blood transfusion is effective for sickle cell anemia-associated priapism. CJEM 2006;8: 119-122.

21 McCarthy LJ, Vattuone J, Weidner J, et al: Do automated red cell exchanges relieve priapism in patients with sickle cell anemia? Ther Apher 2000;4:256-258. 